DOI: 10.22620/agrisci.2021.31.002

\title{
WEED INFESTATION MONITORING IN VINEYARDS IN THE SOUTH SAKAR REGION OF BULGARIA
}

\author{
Iliyan Zheliazkov, Vyara Doycheva, Tsvetelina Ivanova* \\ Agricultural University - Plovdiv \\ *E-mail: cvetelina.iz@mail.bg
}

\begin{abstract}
The weed infestation monitoring was conducted in 2019 and 2020. The purpose was to document the weed flora in a large part of the wine vineyard plots in the cadastral area of the Kolarovo, Ovcharovo, Dositeevo, Balgarin and Izvorovo villages within the administrative territory of the Harmanli municipality and the micro-climatic region of South Sakar.

The established weed species composition was represented by 38 weed species belonging to 18 botanical families in ratio $81.58 \%$ to $18.42 \%$ monocarpous to polycarpous species classified in a total of nine biological groups.
\end{abstract}

Key words: herbicides, weeds, monitoring, vines

\section{INTRODUCTION}

Viticulture used to occupy a prominent place in the Bulgarian agricultural production. Weeds significantly reduce the grapevine fruit yield. They do so first through their direct harmful effect associated with a competition for water and nutrients, and second, indirectly, by contributing to the development of diseases and enemy populations. The effects of uncontrolled weed infestation have to do with reduced yields and quality deterioration of produce. Knowledge of the weed flora of a particular region, area, locality and/or plot is of paramount importance for developing specific weed management strategies.

Weed vegetation in vineyards all over the world is extremely diverse. The reason is the vast diversity of soil, climatic and topographic features as well as the technologies applied in grape growing in a particular area.

Except providing information on the biodiversity of weed species, the present weed infestation survey will help draw some conclusions to confirm those weed species that are resistant to herbicides. This is very important given the limited number of chemical groups permitted for use on grapevines. Due to the absence of crop rotation in these plots for over thirty years and the inability to introduce mechanical methods of weed control within rows, conditions have been created for high levels of resistance in weed species inhabiting plots of permanent crops and vineyards in particular. Once present, resistant weed species can spread rapidly across vineyards and other arable and non-arable land. Weed vegetation monitoring is an important component of weed management systems, and hence each vineyard plot, area and region has to be surveyed thoroughly.

Similar surveys have been conducted in multiple vine-growing areas across the world. In 2017, 78 vineyard plots in 13 regions of the Diyarbakir Province in Turkey were surveyed and a total of 165 weed species belonging to 35 botanical families were identified and recorded (1 parasite, 16 monocotyledonous and 18 dicotyledonous species). Avena sterilis $L$. has the highest density of all the species confirmed in the crops surveyed (Kaçar \& Özaslan, 2020). A study conducted in the $\mathrm{Vršac}$ region of Serbia in 2016 confirmed 97 weed species belonging to 26 botanical families. The diverse 
weed flora in the vineyards of this region showed the following dependencies: therophytes (annual weed species) accounted for $57.73 \%$ and were represented by 4 dominant species: Bromus sterilis L., Echinochloa crusgalli L. Beauv, Hordeum murinum L. and Poa annua $L$. Hemicryptophytes accounted for $34.02 \%$ with the dominant species of Achillea millefolium L., Cichorium intybus L., Galium mollugo L., Hypericum perforatum L., Rumex crispus L. and Sonchus arvensis L. (Anđelković et al., 2020). A study of the weed flora in one of the largest vineyard regions of the Republic of Kosovo - the Rahovec region - has documented a total of 54 weed species, among which Chenopodium album L., Fallopia convolvulus L., Amaranthus retroflexus L., Polygonum aviculare L. and Cirsium arvense L. Scop. (Fetahaj et al., 2017). The authors of a survey conducted in Bosnia and Herzegovina in the period 2006 - 2008 indicated that the most widespread vineyard weed species were Sorghum halepense L. Pers, Amaranthus retroflexus L., Ambrosia artemisiifolia L., Galinsoga parviflora Cav. and Portulaca oleracea L. (Kovačević et al., 2010). Studies conducted in 2001 and 2002 in ten vineyard plots located in six different settlements within the popular vineyard region of Jastrebarsko in Croatia identified the presence of diverse weed flora. 109 weed species were recorded, with the following species confirmed as the most widespread in well-cultivated vineyards: Amaranthus retroflexus L., Chenopodium album L. and Stellaria media L. Vill. The invasive species of Ambrosia artemisiifolia $L$. was recorded in the same areas but the species was presumably introduced into the vineyards from the surrounding/neighbouring habitats. It was concluded that the biennial species of Arctium Lappa $L$. and Artemisia vulgaris $L$. were dominant mostly in abandoned vineyard areas. An oenological view of weed infestation is of considerable importance for weed control in vineyards. According to the authors, the presence of Amaranthus retroflexus L.,
Artemisia vulgaris L., Capsella bursa-pastoris L. Medic. and Daucus carota L. in vineyards leads to quality deterioration of grape, hence quality deterioration of wine (Purgar \& Hulina, 2004). A four-year survey of vineyards was conducted in another "prominent" wineproducing country - Spain. A total of 56 weed species belonging to 26 families were confirmed. The species composition is dominated by the following annual species: Amaranthus spp., Chenopodium album L., Gnaphalium luteo-album L., Poa annua L., Plantago major L., Veronica spp. (Gago et al., 2007).

One of the first studies of weed vegetation in vineyards in Bulgaria was conducted by Ivan Kolev (1963). He confirmed around 80 weed species, 51 of which were most widespread and abundant - 32 annual species and 19 perennial species. According to Kolev, the perennial weeds were of primary importance, and late-spring species were dominant among the annual weeds (Kolev, 1963). The weed indexing of 270 vineyards located in 20 regions in the 1970s showed that the most widespread species were perennial taproot species and fibrous root species. The most common taproot weed was Cynodon dactylon Pers., while Sorghum halepense L. Pers. was less abundant. Second in population size were fibrous root weeds Convolvulus arvensis L. and Cirsium arvense L. Scop., followed by late-spring weeds Amaranthus sp., Chenopodium album L., varieties of Setaria sp., Echinochloa crus-galli L. Beauv., Digitaria sanguinalis L. Scop., Portulaca oleracea L., Solanum nigrum $L$., etc. The ratio of perennial to annual weeds in the intra-row zone is usually 2-2.5 to 1 (Fetvadzieva, 1973).

The purpose of the present study is to establish the weed species composition of weedinfested vineyards in the South Sakar.

MATERIALS AND METHODS 
The weed infestation monitoring was conducted in 2019 and 2020. The primary purpose was to document the weed flora in a large part of the wine vineyard plots in the cadastral area of the Kolarovo, Ovcharovo, Dositeevo, Balgarin and Izvorovo villages. The latter are located within the administrative territory of the Harmanli municipality and the micro-climatic region of South Sakar.

The study covered the red grape varieties traditionally grown in the region - Merlot, Cabernet Franc and Syrah, as well as some white varieties atypical for the region such as Sauvignon Blanc and Chardonnay, over a total area of approximately 700 ha.

From a climatic perspective, the South Sakar region belongs to the ContinentalMediterranean climatic area, South-Bulgarian climatic subarea.

The average total annual amount of precipitation in the region is between 595 and $775 \mathrm{~mm}$. The season peak is in winter, with the highest precipitation amounts recorded in November and December. The lowest precipitation is in summer, mostly in August. The average annual air temperature ranges from $10.0^{\circ}$ to $12.5^{\circ} \mathrm{C}$. Springs are warm, start late and are followed by hot and dry summers. The average sum of the biologically active temperatures for grapevine crops is $3855{ }^{\circ} \mathrm{C}$, with a confidence interval from $3821^{\circ}$ to 3882 ${ }^{\circ} \mathrm{C}$.

The dominant soils are mostly Eutric and Luvic Leptosols, in places strongly affected by erosion, as well as Eutric Vertisols in certain plots and areas. The soil horizon depth is minimal $(70-80 \mathrm{~cm})$. In terms of mechanical composition, the surface horizons of the soils are determined as medium to heavy sandyclayey. The subsoil horizons are determined as light to medium sandy-clayey at a depth of $25-$ $50 \mathrm{~cm}$ and medium to heavy sandy-clayey at a depth of $50-75 \mathrm{~cm}$.

The South Sakar region has unique characteristics for grapevine growing and winery. Its distinctive features are brought together by the notion of the most appropriate terroir for producing high-quality wines.

The survey area covers conventionally grown vineyards, only $2 \%$ of which use drip irrigation systems.

Over the two-year survey period, weed vegetation management in the vineyard row middles was done by means of various physical weed control methods. From the beginning until the middle of the grapevine vegetative cycle (end of July), weeds were removed by means of shallow non-inversion tillage. Mulching (mowing) was applied until harvest time with the aim of preventing weeds from reaching seed production. Deep tillage was performed after harvest, with or without soil horizon inversion.

Various techniques are applied in the different vineyard plots to maintain a weed-free zone under the trellis - from mechanical removal (hand and/or machine weeding) to chemical removal (manual and/or machine herbicide application, directed or broadcast application).

Over the last 25 years, a popular weed control technology used in vineyards in the cadastral area of the Kolarovo and Ovcharovo villages has been total aerial glyphosate-based herbicide application in early spring before bud break. Directed ground application has been used in some of the vineyards in the cadastral area of the Dositeevo, Balgarin and Izvorovo villages. The chemical methods for maintaining the weed grass stand during the grapevine vegetative cycle comprise directed application of total or selective foliar and contact herbicides classified by HRAC according to their mode of action: only Group A products (inhibitors of Acetyl CoA Carboxylase (ACCase)) quizalofopp-ethyl and propaquizafop are applied against gramineous weeds, total foliar contact products: from Group $H$ (inhibitors of glutamine synthetase) - glufosinate; Group D (inhibitors of photosynthesis at photosystem I by electron diversion (PSI inhibitors) - diquat; Group E (inhibitors of protoporphyrinogen oxydase (PPO) - pyraflufen-ethyl; total 
systemic, foliar products from Group $G$ (inhibitors of EPSP synthase)-glyphosate. Soil herbicides are also applied in the weed management of small plots - herbicides of the following groups, alone or combined: Group E - oxyfluorfen; Group K3 (inhibitors of longchain fatty acids /inhibitors of cell division/) s-metolachlor; Group K1 (inhibitors of microtubule assembly) - pendimethalin.
The surveys were conducted in different periods of the year in order to encompass the weed species diversity consistent with their mass emergence periodicity. A weed infestation indexing scheme of the permanent crops surveyed in row middles is enclosed; in order to avoid border row effects, the survey was carried out at a minimal distance of 12 to 15 metres from the first and the end posts of each row. The survey area is shown on Fig. 1.

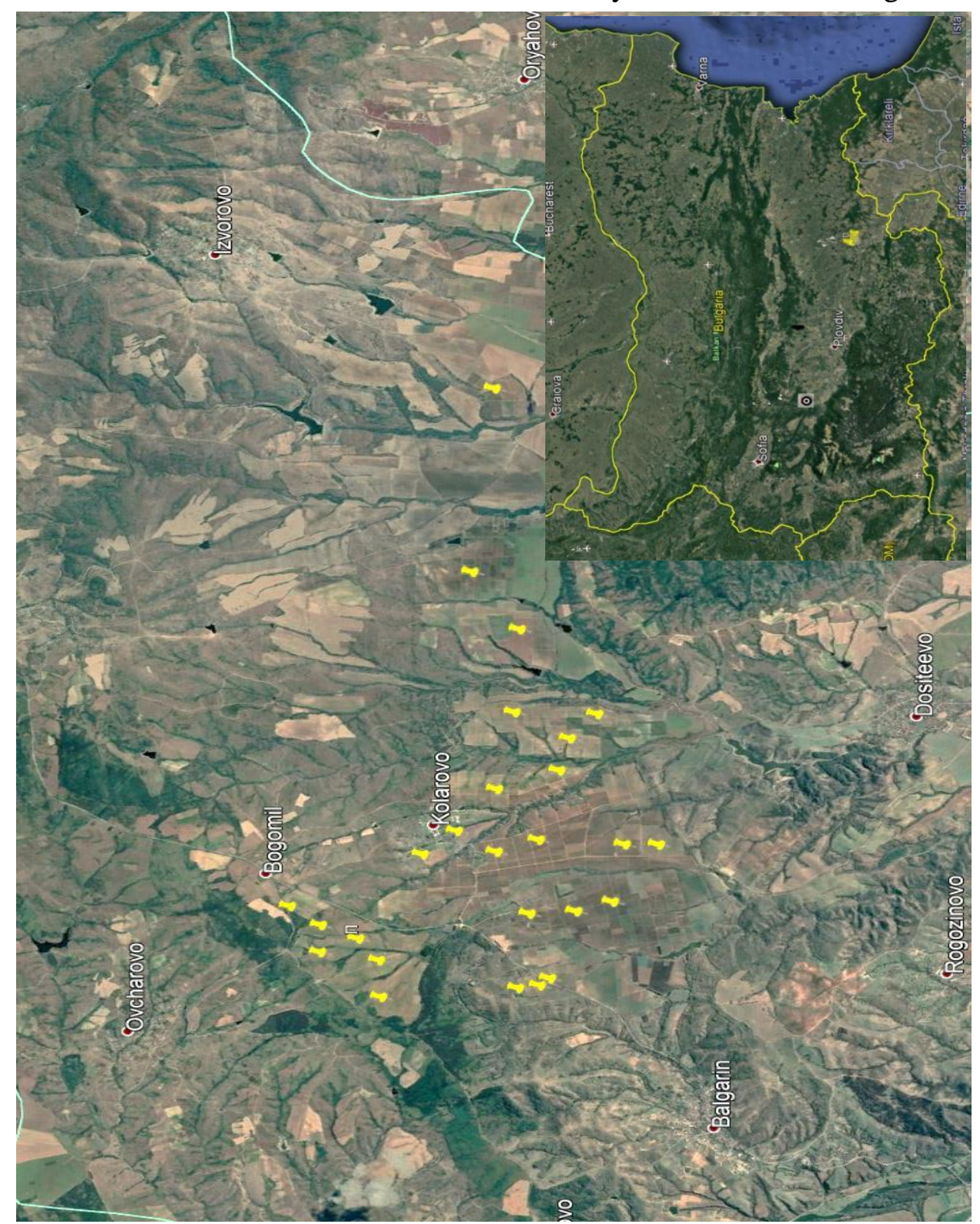

Fig. 1. Map of the survey area

\section{RESULTS AND DISCUSSION}


The weed infestation monitoring conducted in a cross-sectional area of the South Sakar vineyard plots revealed a diverse weed species composition.

The identified weed species composition and distribution showed 38 weed species belonging to 18 botanical families in ratio $81.58 \%$ to $18.42 \%$ monocarpous to polycarpous species classified in a total of nine biological groups. Monocarpous annual species were represented by 31 species from five biological groups shown in percentages (Fig. 2). The highest density, $56 \%$, was in late-spring weed representatives - a total of 18 species, of which two monocotyledonous /gramineous/ species Setaria glauca $L$. and Setaria viridis $L$.
(Poaceae family) accounting for $11.11 \%$ of the entire community, and 16 dicotyledonous species accounting for $88.89 \%$ which belong to eight families - Amaranthaceae (Amaranthus blitoides L.; Amaranthus retroflexus L.; Chenopodium album L.); Asteraceae (Sonchus oleraceus L.; Conyza canadensis L.; Lactuca serriola L.); Xanthium strumarium L.; Xanthium spinosum L.); Boraginaceae (Heliotropium europaeum L.); Malvaceae (Hibiscus trionum L.; Abutilon theophrasti Medic.); Polygonoideae (Polygonum aviculare L.; Polygonum lapathifolium L.); Portulacaceae (Portulaca oleracea L.); Solanaceae (Solanum nigrum L.); Zygophyllaceae (Tribulus terrestris L.).

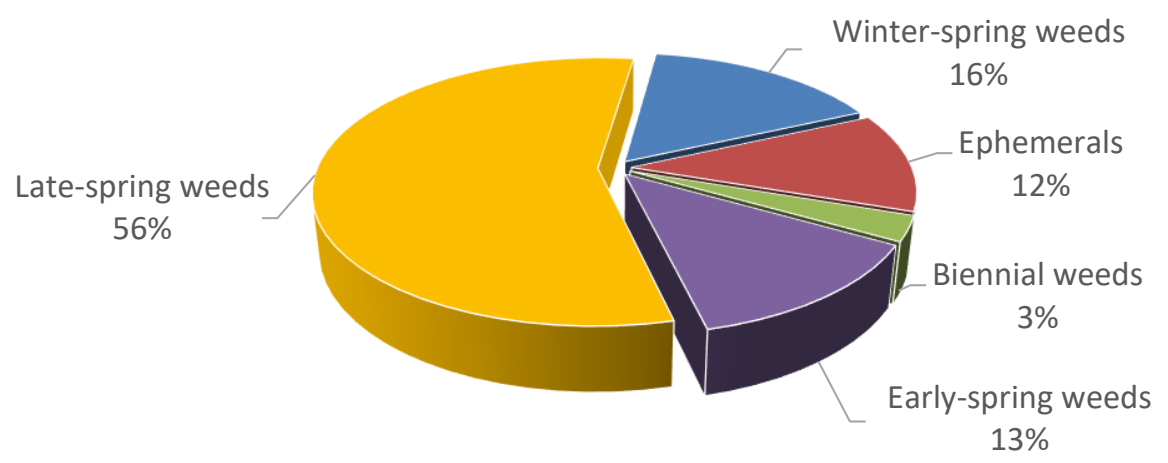

Fig. 2. Distribution of monocarpous, annual weed species in the region of South Sakar, in percentages

The plant species classified in this biological group usually start their growth during the second half of spring when soil temperature remains steady at above $10-15^{\circ} \mathrm{C}$ $\left(20-25^{\circ} \mathrm{C}\right.$ for some species) and new shoots may be detected in vineyard plots almost all year round until late autumn, end of November and beginning of December.

Early soil warming in this part of the country causes some late-spring weed species to develop similarly to early-spring species. Prolific seed reproduction is typical of the species in this group, which guarantees the preservation of the species but also the presence of a huge seed potential in the soil. This calls for annual weed control. Almost all the representatives of this group demonstrate a great ecological plasticity, growing exuberantly in favourable conditions and developing neotenic forms in unfavourable conditions. Winterspring species occupy $16 \%$ of the weed association formed in the vineyards for wine production of the South Sakar. They are represented by five dicotyledonous species of three botanical families - Asteraceae family: Centaurea cyanus L.; Matricaria officinalis L.; Taraxacum officinale Weber; Papaveraceae family - Papaver rhoeas L., and Brassicaceae family - Capsella bursa-pastoris (L.) Medic. Early-spring weeds indexed in the survey area account for $13 \%$ of the species diversity, distributed in four botanical families (Rubiaceae; Brassicaceae; Polygonoideae; Ranunculaceae). The species identified, which belong to the families in the above order, are 
Galium aparine L.; Sinapis arvensis L.; Polygonum convolvulus $L$. and Adonis aestivalis $L$.

The share of ephemeral weeds is $12 \%$, which are represented by four species Stellaria media (L.) Cyr.; Lamium purpureum L.; Veronica hederifolia L.; Fumaria officinalis $L$. from four families: Caryophyllaceae; Lamiaceae; Papaveraceae and Scrophulariaceae. Biennial weeds account for $3 \%$ and are represented only by Malva sylvestris $L$. from the Malvaceae family.

Botanical species determined as weed plants and classified as per their characteristics in the biological groups of ephemerals, earlyspring and winter-spring weeds may at first glance seem harmless for grapevine crops. This is due to the fact that the weeds grow outside the vegetative cycle of the grapevine. In the environment of the survey area, the representatives of these weed groups develop in early spring before buds swell, and new species keep emerging until the end of bloom. This is the first wave of weed species targeted by the first early spring herbicide application in vineyards. The majority of these weeds are considered harmless for grapevines but data by Lenz Moser suggest that the ephemeral species of ivy-leaved speedwell (Veronica hederifolia L.), common chickweed (maruns) (Stellaria media (L.) Cyr.) and red dead-nettle (Lamium purpureum $L$.) have a negative effect on the growth and development of young grapevines, respectively by 3\%, 20\% and 27\%. (Moser, 1970)

Polycarpous perennial species are represented by six weed species from three biological groups: taproot species - Cynodon dactylon (L.) Pers., Sorghum halepense (L.) Pers. (Poaceae family) accounting for $33 \%$ of the perennial species; fibrous root species Convolvulus arvensis L. (Convolvulaceae family), Cirsium arvense (L) Scop., Sonchus arvensis L. (Asteraceae family) representing $50 \%$ of the weed association in vineyards, and $17 \%$ fusiform root weeds represented by Plantago lanceolata L. (Plantaginaceae family). The distribution is visualized in Fig. 3.

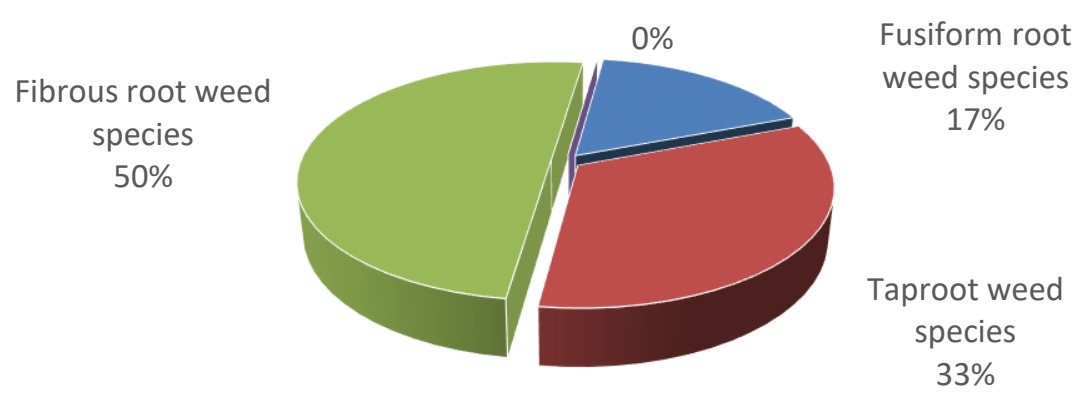

Fig. 3. Distribution of polycarpous, perennial weed species in the South Sakar region, in percentages

\section{CONCLUSION}

1. The weed vegetation monitoring in the South Sakar vineyards shows that the weed flora in the areas surveyed covers 38 botanical species with ratio of monocotyledonous to dicotyledonous species $11.11 \%$ to $88.89 \%$, distributed in eight biological groups, belonging to 18 botanical families.
2. The Asteraceae family has the widest representation in the weed associations of the South Sakar vineyards - a total of ten botanical species distributed in three biological groups winter-spring weeds: Centaurea cyanus $L$; Matricaria officinalis L.; Taraxacum officinale Weber.; late-spring weeds: Conyza canadensis L.; Lactuca serriola (L.); Sonchus arvensis L.; Xanthium spinosum L.; Xanthium strumarium L.; fibrous root weeds: Cirsium arvense $(L)$ 
Scop.; Sonchus arvensis $L$. This family occupies the second place in the world database in terms of the number of registered herbicide-resistant weed species.

3. The lack of rotation of the herbicide use in the chemical weed control in vineyards, coupled with the presence of one and the same species during both years of the survey may be considered the first indications that necessitate conducting annual and regular surveys designed for detecting herbicide-resistant weed plants.

\section{REFERENCES}

Anđelković, P. M., Dragana, L. C. Dušanka, B. R. Snežana \& M. P. Danijela (2020). Biological spectrum of the weed flora in the Vršac vineyards (Serbia). Zbornik Matice srpske za prirodne nauke 139, . 101-11).

Fetahaj, R., Mehmeti, A., Demaj, A., Sherifi, E. \& Waldhardt, R. (2017). Weed flora in vineyards of Rahovec municipality. International Multidisciplinary Scientific GeoConference: SGEM. Sofia, 17. Doi:10.5593/sgem2017/51.

Fetvadzhieva, N. (1973). Borbata s plevelite [The weed control]. Sofia: Zemizdat.

Gago, P., Cabaleiro, C. \& Garcia, J. (2007). Preliminary study of the effect of soil management systems on the adventitious flora of a vineyard in Northwestern Spain. Crop Protection, 26(4), 584-591, ISSN: 0261-2194.

Kaçar, E. P., Özaslan, C. (2020). Weed flora of vineyards in Diyarbakır province, Turkey. Agricultural Science Digest. 40(4), 335-342; 8. Doi:10.18805/ag.D259.

Kolev, I. (1963). .Plevelite v Balgaria [Weeds in Bulgaria] Sofia: BAN [BAS].Kovačević, Z., Petrović, D., Herceg, N., Vego, D. \& Arar, K. (2010). Adventive weed flora in vineyards of Bosnia and Herzegovina. Špičák, Czech
Republic.

Doi:

10.1556/Novenyterm.59.2010.Suppl.1.

Mozer, L. (1970). Novoto lozarstvo [The new viticulture] Sofia: Zemizdat.

Purgar, Dujmović, D. \& Hulina, N. (2004). "Vineyard weed flora in the Jastrebarsko area (NW Croatia)". Acta Botanica Croatica, 63(2), 113-123, https://hrcak.srce.hr/3436. [Last accessed on: 16.03.2021]. 